\title{
Analisis Hambatan Pelaksanaan Eksekusi Pidana Mati pada Pelaku Tindak Pidana Peredaran Narkotika di Dalam Lembaga Pemasyarakatan Dihubungkan dengan Putusan Mahkamah Konstitusi Nomor 107/PUU- XIII/2015
}

\author{
Kania Khairunisa*, Dey Ravena \\ Prodi Ilmu Hukum, Fakultas Hukum, Universitas Islam Bandung, Indonesia. \\ *kaniakhrns@gmail.com, deyravena@yahoo.co.id
}

\begin{abstract}
Narcotics crime is one of the crimes categorized as extraordinary crimes or also called extraordinary crimes. Even though there are special rules on narcotics crimes, they also cannot hold back the circulation of narcotics crimes up to the correctional institutions which can even be carried out by death row inmates who have not yet been executed. This study aims to determine and understand the implementation of law enforcement in Indonesia for prisoners who commit narcotics crime in prison and to analyze what are the factors that hinder the execution of capital punishment in the case of narcotics distribution in prison by convicted prisoners who have been convicted capital punishment is connected with the Constitutional Court Decision Number 107 / PUU-XIII / 2015. This study uses a normative juridical approach. The research specifications used are descriptive analysis. Sources and types of legal materials used are primary legal materials supported by secondary legal materials. The data in this study were obtained through literature study. The data obtained were then analyzed by qualitative analysis methods to obtain conclusions from the problems studied. Based on the results of this research and discussion, it can be concluded that first, the perpetrators of narcotics trafficking offenses carried out in prison can be given prison sanctions and administrative sanctions. Second, the factors that cause obstacles in the implementation of capital punishment include the factors of legislation (legal substance), law enforcement factors, facilities and facilities factors, and community factors.
\end{abstract}

Keywords: Narcotics Crime, Death Penalty, Correctional Institution.

\begin{abstract}
Abstrak. Tindak pidana narkotika merupakan salah satu tindak pidana yang di kategorikan ke dalam kejahatan luar biasa atau disebut juga extraordinary crime. Meskipun telah aturan khusus terhadap tindak pidana narkotika tetapi juga tidak dapat menahan peredaran tindak pidana narkotika hingga di dalam lembaga pemasyarakatan yang bahkan masih bisa dilakukan oleh terpidana hukuman mati yang belum dieksekusi. Penelitian ini bertujuan untuk mengetahui dan memahami pelaksanaan penegakkan hukum di Indonesia terhadap narapidana yang melakukan tindak pidana peredaran narkotika di dalam lembaga pemasyarakatan serta menganalisis apa sajakah faktor yang menghambat terlaksananya eksekusi hukuman atas pidana mati dalam hal peredaran narkotika di dalam lembaga pemasyarakatan oleh narapidana yang telah divonis hukuman mati dihubungkan dengan Putusan Mahkamah Konstitusi Nomor 107/PUU-XIII/2015. Penelitian ini menggunakan metode pendekatan yuridis normatif. Spesifikasi penelitian yang digunakan bersifat deskriptif analisis. Sumber dan jenis bahan hukum yang digunakan adalah bahan hukum primer yang didukung bahan hukum sekunder. Data dalam penelitian ini diperoleh melalui studi kepustakaan. Data yang diperoleh kemudian dianalisis dengan metode analisis kualitatif untuk memperoleh kesimpulan dari permasalahan yang diteliti. Berdasarkan hasil penelitian dan pembahasan ini dapat disimpulkan yaitu pertama, pelaku tindak pidana peredaran narkotika yang dilakukan di dalam lembaga pemasyarakatan dapat diberikan sanksi pidana penjara dan sanksi administrative. Kedua, faktor-faktor yang menjadi penyebab adanya hambatan dalam pelaksaan pidana mati di antaranya ialah faktor perundang - undangan (subtansi hukum), faktor penegakan hukum, faktor sarana dan fasilitas, serta faktor masyarakat.
\end{abstract}

Kata Kunci: Tindak Pidana Narkotika, Hukuman Mati, Lembaga Pemasyarakatan. 


\section{A. Pendahuluan}

Tindak pidana narkotika merupakan salah satu tindak pidana yang di kategorikan ke dalam kejahatan luar biasa atau disebut juga extraordinary crime. Dan sebagai bentuk konkrit dari penanganan tersebut, pemerintah Indonesia telah membuat aturan khususnya atau lex specialis dalam Undang-Undang Nomor 35 Tahun 2009 tentang Narkotika.

Dalam Undang-Undang Nomor 35 Tahun 2009 tentang Narkotika tersebut telah diatur secara komprehensif tentang: penggolongan jenis narkoba, upaya preventif maupun represif, proses peradilan, sanksi, rehabilitasi bagi pecandu narkoba, dan lain-lain. Jika kita mengamati lebih dalam lagi, dalam ketentuan pidana yang di atur dalam Pasal 111-148 Undang-Undang Narkotika juga tidak main-main. Seorang pengedar atau bandar narkoba sekalipun dapat dikenakan pidana penjara paling singkat 5 tahun dan paling berat adalah pidana mati. Tujuan menjatuhkan dan menjalankan hukuman mati selalu diarahkan kepada khalayak ramai agar mereka, dengan ancaman hukuman mati, akan takut melakukan perbuatan - perbuatan kejam yang akan mengakibatkan mereka dihukum mati.

Lembaga Pemasyarakatan juga tidak lepas dari ancaman peredaran dan penyalahgunaan narkotika. Semakin banyaknya pengedar serta pengguna narkotika yang dimasukkan ke dalam lembaga pemasyarakatan juga semakin memberikan celah untuk melakukan peredaran serta penyalahgunaan narkoba yang dilakukan narapidana atau warga binaannya dengan pertolongan atau bekerja sama dengan petugas lembaga pemasyarakatan tersebut. Bahkan narapidana yang telah divonis hukuman matipun masih bisa melakukan pengendalian dan peredaran narkotika dari dalam lembaga pemasyarakatan. Makin banyak penjara disediakan bagi recidivis, masyarakat penjara cenderung semakin penuh dengan sikap - sikap jahat. Dari optik kebijakan kriminal bahwa proses pembinaan narapidana yang telah dilaksanakan selama ini kurang berhasil, salah satu indikator yang bisa dijadikan parameter, semakin tingginya angka reconviction (penghukuman kembali) dan residivis di masyarakat.

Salah satu contohnya adalah kasus pengendalian narkotika dari dalam lembaga pemasyarakatan yang dilakukan oleh narapidana LAPAS Lubuk Pakam Kabupaten Deli Serdang, Medan yaitu Togiman alias Toni alias Toge atau yang dikenal dengan sebutan Toni Toge. Meskipun sudah mengantongi 2 vonis hukuman mati, pelaksanaan eksekusi hukuman mati kepada Toni Toge masih belum ditentukan. Selain kasus Toni Toge juga ada kasus yang serupa yaitu terhadap kasus tindak pidana narkotika Amiruddin alias Amir Aco alias Rahman dimana meskipun sudah divonis hukuman mati, terpidana masih belum dieksekusi.

Berdasarkan contoh tersebut dapat terlihat meskipun terpidana tindak pidana narkotika telah diberikan hukuman yang paling tertinggi yaitu hukuman mati akan tetapi tidak berpengaruh untuk menghentikan para narapidana tersebut untuk melakukan kembali tindak pidana dari dalam lembaga pemasyarakatan. Pemberian hukuman mati bagi Bandar Narkoba merupakan salah satu bentuk keseriusan negara terhadap penanganan kasus narkotika di negara ini. Ekseskusi mati ini sudah dilakukan demi kepentingan dan pelaksanaan hukum yang lebih efektif. Pelaksanaan eksekusi hukuman mati dapat dilaksanankan apabila hak hukum terpidana mati telah terpenuhi. Mengenai tata cara pelaksanaan pidana mati itu sendiri dengan tetap memperhatikan klausul Pasal 10 huruf (a) jo. Pasal 11 KUHP jo. Undang-undang No. 2 /PNPS/ 1964 tentang Tata Cara Pelaksanaan Pidana Mati yang di jatuhkan oleh Pengadilan di lingkungan Peradilan umum dan Militer jo. Peraturan Kapolri No. 12/ 2010 tentang Tata Cara Pelaksanaan Pidana Mati.

Akan tetapi hak hukum terpidana mati seperti Pengujian Kembali (PK) dan pemberian grasi oleh Presiden dapat menjadi alasan terpidana untuk menunda eksekusi hukuman matinya, seperti pada Putusan Mahkamah Konstitusi Nomor 107/PUU-XIII/2015 Tentang Pengujian Undang - Undang Nomor 5 Tahun 2011 Tentang Perubahan Atas Undang - Undang Nomor 22 Tahun 2002 Tentang Grasi Terhadap Undang - Undang Dasar Negara Republik Indonesia Tahun 1945 yang menghapus berlakunya Pasal 7 ayat 2 UU Nomor 5 Tahun 2010 tentang Grasi. Putusan itu mengubah aturan terpidana mengajukan permohonan grasi menjadi kapan saja, dari sebelumnya pengajuan grasi paling lambat dilakukan setahun sejak putusan berkekuatan hukum tetap. 
Berdasarkan latar belakang yang telah diuraikan, maka perumusan masalah dalam penelitian ini sebagai berikut:

1. Bagaimanakah pelaksanaan penegakkan hukum di Indonesia terhadap narapidana yang melakukan tindak pidana peredaran narkotika di dalam lembaga pemasyarakatan?

2. Apakah faktor yang menghambat terlaksananya eksekusi hukuman atas pidana mati dalam hal peredaran narkotika di dalam lembaga pemasyarakatan oleh narapidana yang telah divonis hukuman mati dihubungkan dengan Putusan Mahkamah Konstitusi Nomor 107/PUU-XIII/2015 Tentang Pengujian Undang - Undang Nomor 5 Tahun 2011 Tentang Perubahan Atas Undang - Undang Nomor 22 Tahun 2002 Tentang Grasi Terhadap Undang - Undang Dasar Negara Republik Indonesia Tahun 1945?

\section{B. Landasan Teori}

Negara Indonesia yang merupakan negara hukum ialah negara yang berdiri di atas hukum yang menjamin keadilan kepada warga negaranya. Keadilan merupakan syarat bagi terciptanya kebahagiaan hidup untuk warga negaranya, dan sebagai dasar dari pada keadilan itu perlu diajarkan rasa susila kepada setiap manusia agar ia menjadi warga negara yang baik.

Dalam hal menentukan tentang hambatan dalam suatu penegakkan hukum diperlukan penjabaran terhadap beberapa teori. Kerangka teoretis adalah konsep-konsep yang sebenarnya merupakan abstraksi dari hasil-hasil penelitian atau kerangka acuan yang pada dasarnya untuk mengadakan identifikasi terhadap dimensi-dimensi sosial yang dianggap relevan oleh peneliti.

Berdasarkan definisi tersebut maka kerangka teoritis yang digunakan dalam penelitian ini adalah teori penanggulangan kejahatan dan teori faktor-faktor yang menghambat penegakan hukum pidana. Juga adanya teori pemidanaan yang dimana teori - teori ini mencari dan menerangkan tentang dasar dari hak negara dalam menjatuhkan dan menjalankan pidana tersebut serta teori-teori yang mendukung tujuan pemidanaan menurut hukum pidana ada tiga macam yaitu teori absolut, teori relative dan teori gabungan. Dalam hal ini pidana dan pemidanaan terdiri dari proses kegiatan terhadap pelaku tindak pidana, yang dengan suatu cara tertentu diharapkan dapat mengasimilasikan kembali narapidana kemasyarakat. Secara serentak, masyarakat menuntut agar memperlakukan individu tersebut juga dapat memuaskan permintaan atau kebutuhan pembalasan.

Selain teori pemidanaan, teori faktor-faktor yang menghambat penegakan hukum pidana yaitu menurut Soerjono Soekanto, penegakan hukum bukan semata-mata pelaksanaan perundang-undangan saja, namun terdapat juga faktor-faktor yang mempengaruhinya, yaitu sebagai Faktor Perundang-undangan (Substansi hukum), Faktor penegak hukum, Faktor sarana dan fasilitas, Faktor masyarakat, dan Faktor kebudayaan. Sedangkan kerangka konseptual adalah kerangka yang menggambarkan hubungan antara konsep-konsep khusus yang merupakan kumpulan dari arti-arti yang berkaitan dengan istilah yang diinginkan dan diteliti.

\section{Hasil Penelitian dan Pembahasan}

\section{Pengaturan Pelaksanaan Penegakan Hukum di Indonesia terhadap Narapidana yang Melakukan Tindak Pidana Peredaran Narkotika di Dalam Lembaga Pemasyarakatan Perlindungan Hukum}

Penegakan hukum di Indonesia terhadap tindak pidana narkotika dilaksanakan berdasarkan Undang-Undang Dasar 1945 dan aturan khususnya (lex specialis) dalam Undang-Undang Nomor 35 tahun 2009 tentang Narkotika.

Kajian secara sistematis terhadap penegakan hukum dan keadilan secara teoritis dinyatakan efektif apabila 5 (lima) pilar hukum berjalan baik. Soerjono Soekanto mengatakan bahwa penegakan hukum adalah sarana yang didalamnya terkandung nilai atau konsep tentang keadilan, kebenaran, kemanfaatan sosial dan kandungan hukum bersifat abstrak. Penegakan hukum secara konkret merupakan berlakunya hukum positif dalam praktek sebagaimana seharusnya dipatuhi. Oleh karena itu keberhasilan penegakan hukum dipengaruhi oleh 5 faktor yang mempengaruhi penegakan hukum, yaitu Faktor hukumnya sendiri, Faktor penegak hukum, yaitu pihak yang membentuk maupun menetapkan hukum, Faktor sarana atau fasilitas yang mendukung penegakan hukum, Faktor masyarakat yakni, lingkungan dimana hukum tersebut 
berlaku dan diterapkan, dan Faktor kebudayaan yakni, sebagai hasil karya cipta rasa yang didasarkan pada karsa manusia dalam pergaulan hidup.

Peredaran narkotika di dalam Lapas merupakan suatu pelanggaran hukum, yang merupakan bentuk larangan seperti yang tertulis di dalam Pasal 4 ayat (g) Peraturan Menteri Nomor 6 Tahun 2013 Tentang Tata Tertib Lembaga Pemasyarakatan Dan Rumah Tahanan. Maka dari itu harus dikenakan sanksi yang berlaku sesuai ketentuan Pasal 10 ayat (3) point $h$ Peraturan Menteri Nomor 6 Tahun 2013 Tentang Tata Tertib Lembaga Pemasyarakatan Dan Rumah Tahanan.

Dalam penjatuhan sanksi bagi pelaku tindak pidana khususnya pengedar seperti kasus terpidana Togiman alias Toni alias Toge atau yang lebih dikenal sebagai Tony Toge yang meskipun sedang melaksanakan masa tahanan sebagai menjalani pidana di dalam Lembaga Pemasyarakatan Lubuk Pakam Kab. Deli Serdang dikarenakan kasus peredaran narkotika sebelumnya, maka kepadanya diberlakukannya Pasal 114 ayat (2) jo. Pasal 132 ayat (1) Undang-Undang No. 35 Tahun 2009 Tentang Narkotika.

Berdasarkan pemaparan diatas pelaku tindak pidana peredaran narkotika yang dilakukan di dalam lembaga pemasyarkatan yang terdiri dari narapidana, dan sipir atau petugas Lapas yang dalam hal ini, penegakan hukum yang dilakukan adalah berdasarkan UndangUndang Nomor 35 Tahun 2009 Tentang Narkotika, dengan sanksi pidana penjara terhadap sipir atau petugas lapas dan berdasarkan Peraturan Menteri Hukum dan HAM Nomor 6 Tahun 2013 Tentang Tata Tertib Lembaga Pemasyarakatan Dan Rumah Tahanan yaitu berupa penjatuhan sanksi administrative terhadap narapidana.

Faktor Penghambat Terlaksananya Eksekusi Hukuman Atas Pidana Mati dalam Hal Peredaran Narkotika di Dalam Lembaga Pemasyarakatan oleh Narapidana yang Telah Divonis Hukuman Mati Dihubungkan dengan Putusan Mahkamah Konstitusi Nomor 107/Puu-XIII/2015

Berbicara tentang faktor penghambat dalam pelaksanaan eksekusi hukuman pidana mati, telah dijabarkan bahwa di Indonesia para terpidana yang dikenakan pidana mati diberikan hak untuk mengajukan upaya hukum, baik yang berupa upaya hukum biasa, upaya hukum luar biasa yang diatur dalam Kitab Undang-Undang Hukum Acara Pidana (KUHAP) maupun upaya hukum di luar KUHP, yaitu di antaranya upaya hukum Grasi. Upaya hukum adalah hak yang diberikan hakim kepada para pihak dalam suatu perkara untuk dapat tidak setuju dengan suatu putusan pengadilan. Grasi merupakan bentuk pengampunan dari presiden setelah terpidana mengajukan permohonan kepada Presiden, sedangkan amnesti dan abolisi merupakan pengampunan yang diberikan oleh presiden kepada terpidana dengan memperhatikan pertimbangan dari Dewan Perwakilan Rakyat, tanpa ada permohonan dari terpidana.

Melihat hubungan grasi dengan tujuan pemidanaan, terlepas dari hal-hal tersebut diatas, mengenai pemberian grasi harus didasarkan pada tujuan pemidanaan, presiden baik mengabulkan atau menolak permohonan grasi yang diajukan, haruslah disandarkan pada tujuan pemidanaan. Artinya dalam permohonan grasi ini presiden harus mempertimbangkan masalah pembalasan juga tidak lupa mempertimbangkan masalah mengenai perlindungan tertib hukum masyarakat, baik mengabulkan atau menolak permohonan grasi dari permohonan. Dalam hal ini masukan dari Mahkamah Agung sangat diperlukan oleh presiden sebagai badan yang memang brekompeten untuk itu, dalam pengambilan putusan oleh presiden.

Pada kasus pengendalian narkotika dari dalam lembaga pemasyarakatan yang dilakukan oleh narapidana Lembaga Pemasyarakatan Lubuk Pakam Kabupaten Deli Serdang, Medan yaitu Togiman alias Toni alias Toge atau yang dikenal dengan sebutan Tony Toge dan kasus pengendalian narkoba di dalam lembaga pemasyarakatan oleh Amiruddin alias Amir Aco alias Rahmandimana, yang kedua orang tersebut telah mendapatkan vonis hukuman mati lebih dari satu kali tetapi di saat sedang melaksanakan masa pidana masih dapat melakukan tindak pidana narkotika dari dalam lapas.

Seharusnya setelah adanya in kracht pelaksanaan eksekusi hukuman mati segera dilaksanakan, akan tetapi pidana mati hanya bisa dilaksanaan apabila terhadap tindak pidana tersebut sudah dijatuhi putusan in kracht atau sudah tidak ada upaya hukum yang dilakukan oleh terpidana dan penasihat hukumnya. Dalam menuntukan waktu eksekusi pidana mati memang 
Kejaksaan Agung yang bertanggung jawab. Namun Kejaksaan Agung bukan satu-satunya yang menjadi penanggung jawab. Karena pihak Kejaksaan Agung harus berkerjasama dengan pihak dari instansi-instansi lain seperti Kepolisian, Brimob, Rumah Sakit dan pihak tempat dimana eksekusi akan dilaksanakan.

Faktor-faktor yang menjadi penyebab adanya hambatan dalam pelaksanaan pidana mati di antaranya ialah faktor perundang - undangan (subtansi hukum), faktor penegakan hukum, faktor sarana dan fasilitas, serta faktor masyarakat. Penjelasannya adalah sebagai berikut:

1. Faktor perundang-undangan (substansi hukum) berkaitan mengenai praktek penyelenggaraan penegakan hukum. Dalam penentuan waktu pelaksanaan eksekusi pidana mati pihak kejaksaan diberikan wewenang untuk menentukan berdasarkan pertimbangan- pertimbahan yang ada. Karena belum adanya pengaturan mengenai durasi waktu dari putusan in kracht hingga hari pelaksanaan pidana mati. Pertimbanganpertimbangan dari kejaksaan merupakan kebijakan yang tidak sepenuhnya berdasarkan hukum tertulis tetapi dapat dianggap sebagai sesuatu yang dapat dibenarkan sepanjang kebijakan tidak bertentangan dengan hukum. Salah satu contoh dalam faktor perundangundangan yaitu Putusan Mahkamah Konstitusi Nomor 107/PUU-XIII/2015 Tentang Pengujian Undang - Undang Nomor 5 Tahun 2011 Tentang Perubahan Atas Undang Undang Nomor 22 Tahun 2002 Tentang Grasi Terhadap Undang - Undang Dasar Negara Republik Indonesia Tahun 1945 yang menghapus berlakunya Pasal 7 ayat 2 UU No 5 Tahun 2010 tentang Grasi. Putusan itu mengubah aturan terpidana mengajukan permohonan grasi menjadi kapan saja, dari sebelumnya pengajuan grasi paling lambat dilakukan setahun sejak putusan berkekuatan hukum tetap, sehingga implikasi dengan tidak ada pembatasan tenggang waktu dalam pengajuan grasi, maka pelaksana putusan pemidanaan terpengaruh dengan ketentuan tersebut. Terjadinya ketidakpastian hukum dalam melaksanakan eksekusi hukuman mati karena terpidana menunda-nunda eksekusi pidana mati. Prosedur grasi yang cukup lama inilah yang sering kali menghambat jalannya eksekusi, sehingga grasi dijadikan upaya untuk menghindari hukuman mati.

2. Faktor penegakan hukum berkaitan dengan mentalitas atau kepribadian dari penegak hukum. Kembali lagi karena penentukan pelaksanaan pidana mati diserahkan kepada pihak kejaksaan maka sikap dan peran kejaksaan secara pribadi sangat perperan dalam hal ini. Bagaimana jaksa itu bertanggung jawab atas tugas yang sudah dipercayakan kepadanya seperti pidana mati yang seharusnya dilaksanakan segera agar tidak menambah penderitaan terpidana.

3. Faktor sarana dan fasilitas sangat berperan penting dalam hal pelaksanaan pidana mati. Pelaksanaan eksekusi pidana mati diatur dalam Undang-Undang No.2/PNPS/1964 tentang Tata Cara Pelaksanaan Pidana Mati yang Dijatuhkan oleh Pengadilan di Lingkungan Peradilan Umum dan Militer.

\section{Kesimpulan}

Berdasarkan pembahasan dalam penelitian ini, peneliti menyimpulkan beberapa hasil penelitian sebagai berikut:

1. Penegakan hukum ditujukan guna meningkatkan ketertiban dan kepastian hukum dalam masyarakat. Penegakan hukum di Indonesia terhadap tindak pidana narkotika dilaksanakan berdasarkan Undang-Undang Dasar 1945 dan aturan khususnya (lex specialis) dalam Undang-Undang Nomor 35 tahun 2009 tentang Narkotika. Keberhasilan penegakan hukum dipengaruhi oleh 5 faktor yang mempengaruhi penegakan hukum. Serta peredaran narkotika di dalam Lembaga Pemasyarakatan merupakan suatu pelanggaran hukum, maka dari itu harus dikenakan sanksi yang berlaku sesuai ketentuan Peraturan Menteri Hukum dan HAM Nomor 6 Tahun 2013 Tentang Tata Tertib Lembaga Pemasyarakatan Dan Rumah Tahanan yaitu berupa hukuman disiplin atau penjatuhan sanksi administrative yang diberikan kepada narapidana atau tahanan yang melakukan tindak pidana peredaran narkotika, serta hukuman berupa sanksi pidana kepada sipir atau petugas lapas yang mengacu pada Undang-Undang Nomor 35 Tahun 2009 Tentang Narkotika, yaitu bisa berupa sanksi pidana penjara, pidana mati, pidana seumur hidup, 
dan pidana denda.

2. Faktor-faktor yang menjadi penyebab adanya hambatan dalam pelaksaan pidana mati di antaranya ialah faktor perundang - undangan (subtansi hukum), faktor penegakan hukum, faktor sarana dan fasilitas, serta faktor masyarakat.

\section{E. Saran}

1. Dikarenakan Undang - Undang Grasi yang saat ini sedang berlaku mengatur tidak adanya pembatasan waktu dalam proses pengajuan grasi berdasarkan Putusan Mahkamah Konstitusi Nomor : 107/PUU-XIII/2015 dapat disalah gunakan oleh berbagai pihak yang mempunyai rencana untuk mengulur waktu dan juga celah untuk dapat melakukan tindak pidana lainnya di dalam lembaga pemasyarakatan disaat terpidana menunggu kepastian pemenuhan hak khusus atau upaya hukum terpidana sebelum dapat dilaksanakan eksekusi hukuman mati kepadanya. Sehingga diperlukan penjelasan lebih jelas dan terperinci tentang grasi, dikarenakan grasi yang merupakan upaya akhir yang diberikan kepada terpidana dalam upaya hukum luar biasa yang dapat diajukan oleh terpidana seharusnya diberikan batasan waktu demi terciptanya kepastian hukum.

2. Pelaksanaan eksekusi hukuman mati terhadap narapidana yang telah memiliki keputusan tetap dan kuat (in kracht) di pengadilan seharusnya segera dilaksanakan, maka dari itu dalam hal penggunaan hak khusus atau upaya hukum terpidana mati seperti mengajukan grasi dapat terpenuhi, dalam hal ini diperlukan kejaksaan yang harus lebih aktif menanyakan terpidana mati dan atau keluarganya tentang penggunaan hak khusus yang masih belum terpakai, agar kepastian nasib terpidana lebih jelas dan mencegah terpidana dapat melakukan tindak pidana lain di dalam lembaga pemasyarakatan disaat sedang menunggu eksekusi, juga agar kepastian hukum terpenuhi dimana sesuai dengan saran yang terdapat pada Putusan Mahkamah Konstitusi Nomor 107/PUU-XIII/2015.

\section{Daftar Pustaka}

[1] Anton Sudarto, Penerapan Hukum Pidana Narkotika di Indonesia, ADIL: Jurnal Hukum, Vol. 7 No.1, Tahun 2016.

[2] Atet Sumanto, Efektifitas Pidana Mati Dalam Proses Penegakan Hukum Tindak Pidana Narkotika, Prespektif, Volume 22 No.1 Tahun 2017 Edisi Januari.

[3] Barda Nawawi Arief, Bunga Rampai Kebijakan Hukum Pidana, Aditya Bakti, Bandung, 2002.

[4] Dey Ravena, Implikasi Nilai Keadilan Pembinaan Narapidana di Indonesia, Scientica Jurnal Sosial Humaniora (Hukum, Manajemen, Psikologi, Pendidikan, Komunikasi), Vol 4 No.1 Tahun 2017.

[5] Edi Setiadi dan Dian Andriasari, Perkembangan Hukum Pidana di Indonesia, Graha Ilmu, Yogyakarta, 2013.

[6] Ferawati, “Jurnal Ilmu Hukum”, VOLUME 4 NO. 3, September 2014-Januari 2015.

[7] Luhut M.P. Pangaribuan, Hukum Acara Pidana: Surat-surat Resmi di Pengadilan oleh Advokat, Djambatan, Jakarta, 2002.

[8] Moh.Kusnardi dan Harmaily Ibrahim, Hukum Tata Negara Indonesia, Sinar Bakti, Jakarta 1988.

[9] Putusan Nomor: 68/Pid.Sus/2017/PT.MDN.

[10] Sanyoto, Penegakan Hukum Di Indonesia, Jurnal Dinamika Hukum, Vol. 8 No. 3, September 2008.

[11] Soerjono Soekanto, Faktor-faktor yang mempengaruhi Penegakan Hukum, PT Raja Grafindo Persada, 1983.

[12] Soerjono Soekanto, Pengantar Penelitian Hukum, Rineka Cipta, Jakarta, 1986.

[13] Wirjono Prodjodikoro, Asas - Asas Hukum Pidana di Indonesia, PT. Refika Aditama, Bandung, 2003. 